Article

\title{
Examining the Emergence and Evolution of Blue Ocean Strategy through the Lens of Management Fashion Theory
}

\author{
Dag Øivind Madsen * ${ }^{(1)}$ and Kåre Slåtten \\ Department of Business, Marketing and Law, School of Business, University of South-Eastern Norway, \\ Bredalsveien 14, 3511 Hønefoss, Norway; kare.slatten@usn.no \\ * Correspondence: dagm@usn.no; Tel.: +47-31008732
}

Received: 28 November 2018; Accepted: 8 January 2019; Published: 18 January 2019

check for updates

\begin{abstract}
Blue Ocean Strategy (BOS) is a management concept which prescribes that organizations, rather than going head-to-head with competitors, try to create and exploit new market spaces, so-called blue oceans. Since its inception in the mid-2000s, BOS has become one of the most popular concepts in the field of strategy and one of the biggest buzzwords in the business world. This paper examines the emergence and evolution of BOS through the lens of management fashion theory. The analysis shows that the BOS concept exhibits several characteristics which makes it highly appealing to organizations and managers. In addition, the emergence of the concept was helped by a good fit with the zeitgeist in the field of strategy during the 2000s, which had shifted to a strong focus on theories and ideas about disruptive innovation and business model innovation. The popularization of the BOS concept can also be attributed to the backing of a powerful supply-side actors, and, in particular, the concept's creators Kim and Mauborgne. While the attention given to BOS in public management discourse suggests that the concept can currently be considered highly fashionable, evidence about the concept's use on the demand-side remains limited. Most surveys indicate that the adoption and diffusion is lower than would be expected based on the intensity of discourse surrounding the concept. Therefore, the current study provides some support for the view that supply-side and demand-side activity related to management fashions does not necessarily coevolve.
\end{abstract}

Keywords: Blue Ocean Strategy; management concept; strategy concept; emergence; evolution; popularity; management fashion

\section{Introduction}

\subsection{Blue Ocean Strategy}

Blue Ocean Strategy (BOS) is a strategy concept which was introduced in the mid-2000s by W. Chan Kim and Renée Mauborgne (KM), professors at the well-regarded business school INSEAD (Kim and Mauborgne 2004, 2005b). The BOS concept was presented as a radical shift from the conventional paradigm and ways of thinking in the field of strategic management over the last few decades. According to Denning (2017a), KM started a "revolution" in the field of strategy.

The main idea behind BOS is rather simple. Instead of trying to outcompete competitors in established and crowded market spaces ("red oceans" where shark-like competitors bloody the waters), KM suggest that organizations should seek out uncontested market spaces, so-called "blue oceans" where they can "swim" freely.

Since its introduction a bit more than a decade ago, BOS has attracted enormous attention in the business world (Agnihotri 2016; Denning 2017a; Holiday 2017). There is little doubt that the 
concept is currently one of the strategy field's biggest buzzwords, frequently talked about and used by consultants and practitioners. The original BOS book from 2005 (Kim and Mauborgne 2005b) has become a worldwide hit, and has made several bestseller lists, for example the lists published by Wall Street Journal, BusinessWeek, and Amazon.com (Parvinen et al. 2011). Various sources report that the book has sold close to 4 million copies worldwide and been translated into more than 40 languages (Holiday 2017).

The commercial success of the BOS book has catapulted the duo to fame in the business world. For example, the influential business school blog Poets and Quants refers to KM as "celebrity strategy professors" ${ }^{\prime 1}$. The concept has become part of the accepted body of knowledge in the field of strategic management. For example, BOS has become incorporated in textbooks and curricula in strategic management education, and is covered in some of the most influential strategy textbooks (Hill et al. 2017, pp. 164-65; Johnson et al. 2017, p. 85). There are also various encyclopedia entries about BOS (Low and Ang 2013; Mi 2015). Moreover, BOS is covered in recent MBA-style handbooks aimed at an audience of practitioners (Birkinshaw and Mark 2015, 2017). This indicates that the term has become part of the terminology in the field of strategy and management.

\subsection{Purpose and Contribution}

Based on the observations above, it is clear that BOS in just a bit over a decade has become a very popular and "buzzing" concept in the field of strategy. However, since more than a decade has passed since the concept's inception, we believe the time is ripe to examine the historical emergence and evolution of the BOS concept. In our view, there is a clear need to scrutinize the concept of BOS and examine why it has become such an enormous commercial success and why it has risen to prominence among strategy consultants and practitioners.

Some researchers have touched on similar issues in prior research. For example, it has been pointed out that the introduction and popularization of BOS has been an "excellent marketing endeavor" with an "intelligent and well-targeted communication campaign" (Gandellini and Venanzi 2011, p. 4). However, researchers have also pointed out that there are some actors who remain critical of BOS. For example, in the words of Parvinen et al. (2011, p. 1219), "the internet is full of references to blogs, book reviews, business books and discussion forum entries criticizing BOS."

These observations of a contested field around BOS, consisting of a number of actors acting as cheerleaders and fans of BOS as well as critics questioning the legitimacy of the concept, suggests that the "management fashion perspective" (e.g., Abrahamson 1996; Benders and Van Veen 2001; Kieser 1997) could be a suitable lens for understanding the emergence and evolution of the concept.

The management fashion perspective puts emphasis on the supply and demand dynamics in the market for management concepts and ideas (Abrahamson et al. 2015). The management fashion lens can be especially useful for tracing the popularity trajectories of management concepts since the theory focuses on the diffusion and evolution of popular concepts at the macro-level rather than their implementation at the organizational level (Madsen and Slåtten 2015b; Perkmann and Spicer 2008).

To the best of the authors' knowledge, no other study has explicitly drawn on management fashion theory to shed light on the emergence and evolution of BOS as a fashionable management concept in the field of strategy. However, previous research has shown that the management fashion theory has explanatory power in the context of the field of strategy. For example, researchers have used management fashion theory to cast light on the workings and dynamics of the field of strategy, which is populated by a number of different fashion-setting actors such as strategy consultants and strategy gurus (T. Clark 2004a). Moreover, researchers have shown that such actors shape the legitimacy and popularity of different strategy concepts, tools and techniques, and, in turn, which of these "stick around" as institutionalized strategy practices (Jarzabkowski and Kaplan 2015).

1 https://poetsandquants.com/2017/09/27/celebrity-strategy-professors-latest-book-blue-ocean-shift/. 


\subsection{Research Approach}

The research in this paper is undertaken using a theoretical and exploratory approach. Since the purpose of the paper is to examine the emergence and evolution of BOS, data about the concept from both a supply-side and a demand-side perspective are utilized. Insights from a variety of sources are synthesized to "paint a picture" (Nijholt and Benders 2007) or create a "mosaic picture" (Morrison and Wensley 1991, p. 116) of the period from the concept's inception (mid 2000s) to the present time. There are admittedly potential limitations associated with relying heavily on secondary sources to study management concepts (Nijholt and Benders 2007, p. 649), but it is, in our view, a pragmatic methodological choice given the many challenges associated with gathering data on the interest in and use of management concepts (see e.g., Braam et al. 2007, p. 876), particularly in a historical perspective.

\subsection{Structure}

The rest of the paper is organized in the following way. Section 2 provides a brief introduction to the historical emergence and evolution of BOS. Section 3 takes a closer look at the concept's characteristics and evaluates its potential as a management fashion. In Sections 4 and 5 the supply and demand sides of BOS are analyzed. Section 6 discusses the findings in the context of research on fashionable management concepts and the management fashion perspective more generally. Finally, Section 7 concludes the paper by summarizing contributions, limitations, and ideas for future studies.

\section{A Brief History of BOS}

\subsection{Emergence and Evolution}

KM's concept of BOS is the "product of a successful twenty-year research and consultancy partnership" (Leavy 2005, p. 13). The concept of BOS was introduced in 2004 in a Harvard Business Review article titled "Blue Ocean Strategy" (Kim and Mauborgne 2004). In the following year, the concept was fleshed out in a book published by the Harvard Business School Press (Kim and Mauborgne 2005b). It is safe to say that the term quickly caught on in the business community, and has since then "grasped the utmost attention amongst academic scholars and managers" (Agnihotri 2016, p. 519).

Over the course of the last 10-15 years, the BOS book has become a worldwide management bestseller and translated to more than 40 languages across five continents (Welch and Edmondson 2012). The book sold more than 1 million copies in its first year (Savage and Brommels 2008). By the mid-2010s it had sold more than 3 million copies (Parvinen et al. 2011, p. 1219). As of 2017, the book had reportedly sold close to four million copies (Holiday 2017).

KM have taken a leading role in the conceptual development and evolution of BOS. Over the course of the last decade, KM have published a steady stream of books and articles where they have developed and elaborated on the initial concept (Kim and Mauborgne 2005a, 2009, 2014, 2015a, 2015b). They have also developed educational materials (e.g., cases, teaching notes) for use in MBA and executive education courses about BOS (e.g., Kim et al. 2013, 2016). In 2017, KM published the "Blue Ocean Strategy Reader," a collection of the earlier articles (Kim and Mauborgne 2017a) as well as a new version of the BOS book titled "Blue Ocean Shift" (www.blueoceanshift.com) (Kim and Mauborgne 2017b).

\subsection{Fit with the Zeitgeist}

BOS was introduced during the mid-2000s and fit well with the dominant zeitgeist in the strategy field at the time. Around the turn of the millennium, the strategy field shifted towards a heavier emphasis on theoretical ideas such as disruptive innovations and business model innovation (Foss and Saebi 2017; Kumaraswamy et al. 2018; Massa and Tucci 2013; Planellas 2017). Moreover, during the 1990s other management gurus had prepared the ground for BOS in different ways. For example, in the field of strategy C. K. Prahalad and Gary Hamel did important initial trailblazing by introducing new influential ideas about the nature of competition and the role of core competencies in the new 
economy (Hamel and Prahalad 1994; Prahalad and Hamel 1990, 1994). As noted by Leavy (2010), in the book "Competing for the Future", Prahalad and Hamel introduced the notion of "white space" which refers to the challenges associated with creating new market spaces. KM's notion of creating "blue oceans" is clearly similar to and building on these thoughts.

\subsection{Links between BOS and Other Management Concepts and Ideas}

The concept of BOS also has links to several other contemporary management ideas which emerged during the 1990s and gained in popularity after the turn of the millennium. Examples include Clayton Christensen's notion of disruptive innovation (Christensen 1997, 2006) as well as business model innovation (Chesbrough 2010; Johnson 2010). Similarly, BOS has an explicit focus on innovation, as the concept builds heavily on the notion of value innovation which KM discussed in an earlier article (Kim and Mauborgne 1997). Value innovation involves delivering higher value at a lower cost, thereby making competitors obsolete.

Several researchers (e.g., Gandellini and Venanzi 2011; Parvinen et al. 2011) have noted that BOS builds on existing and well-established theories and concepts in the strategy literature, e.g., the frameworks introduced by Ansoff, Porter, Levitt, and Hamel/Prahalad. Therefore, it could be questioned whether BOS is actually an innovative strategy concept, or whether it is mostly a clever reframing of older ideas in the strategy field, i.e., "old wine in new bottles" (cf. Spell 1999; Örtenblad 2007).

\subsection{Popularity Trajectory}

As noted previously, BOS is relatively nascent phenomenon in the field of strategy, having emerged in the mid-2000s. The concept has only really been part of the discourse and practice in the field of strategy for a little over a decade. Hence, it is not necessary to go far back in order to establish a historical overview of the concept's popularity trajectory.

Based on readings of various writings on BOS, it is clear that the concept has been a huge commercial success. The sales of the BOS book indicate that the concept currently has a large share of popular management discourse, which is an indication that the concept has become a fashionable management concept (cf. Jung and Kieser 2012, p. 329). The fact that the BOS book has been translated into multiple languages and has won awards and accolades in non-western economies such as China, Russia, and Vietnam suggests a broad worldwide acceptance and institutionalization of the BOS ideas. The sales figures of the BOS book suggest that there is much appetite for the BOS ideas among managers in organizational practice. However, there is little evidence on the actual take-up of the concept in practice. Therefore, it is difficult to know to what extent the hype and buzz surrounding BOS has resulted in actual changes in organizations.

\section{The Characteristics of the BOS Concept}

In this section we will take a closer look at the characteristics of the BOS concept. First, however, we will take a step back and briefly discuss the role of management concepts in the field of strategy. Second, we examine and analyze the characteristics of the BOS concept. Third, we evaluate the characteristics of the BOS concept and whether it has potential as a management fashion, i.e., whether KM have used the "winning formula" and "secret sauce" needed to create a popular management concept.

\subsection{Management Concepts in the Field of Strategy}

First, we will briefly take a look at the distinction between management and strategy concepts. In the field of management and organization studies, management concepts are defined as prescriptive ideas on management known by a particular label (Benders and Verlaar 2003). Well-known examples of management concepts include Total Quality Management (TQM), Business Process Reengineering (BPR) and Lean Production (LP). 
The field of strategic management is littered with many types of strategic frameworks, concepts and tools (D. N. Clark 1997, p. 417). Some of the more famous examples include Porter's Five Forces, the BCG Matrix, Balanced Scorecard, SWOT Analysis and McKinsey 7S (Jarzabkowski and Kaplan 2015; Rasche and Seidl 2017; Stenfors 2007). Strategy scholars sometimes refer to these concepts as "general strategy concepts" (Rasche and Seidl 2017; Seidl 2007). Generally, such concepts aim to help managers in the various phases of crafting, implementing, and executing strategic plans. While these various strategy concepts have similarities, they also have different foci. For example, the BCG Matrix is primarily presented as a technique for corporate portfolio planning (Madsen 2017), while the Balanced Scorecard is presented as a more holistic strategic management concept which can help an organization implement and execute its strategy (Kaplan and Norton 2008).

\subsection{Characteristics}

In the following, we will focus on analyzing the BOS concept using four key characteristics of management concepts identified by researchers based on in-depth studies of well-known management fashions such as Business Process Reengineering and Total Quality Management (Benders and Van Veen 2001; Huczynski 1992; Røvik 2002). These characteristics are related to how a concept is labelled, whether the concept can be interpreted in different ways, whether performance improvements are promised to prospective adopters, and whether the concept is presented as having universal applicability. According to Røvik (2002), a concept that exhibits such characteristics to a high degree (i.e., follows the "winning formula"), will have a greater potential to "flow" widely and easily in the management community. This means that it becomes more likely that the concept will become popular and fashionable.

\subsubsection{Label}

Fashionable management concepts tend to be labeled in a distinctive way, usually using a catchy and fancy label which is easy to remember for busy managers (Kieser 1997; Røvik 1998). The BOS concept scores very high on this criterion, as the label is arguably very catchy. As pointed out by Gandellini and Venanzi (2011, p. 4) BOS is "based on the expedient of an original title, an intriguing subtitle, new labels for several old concepts and similar views expressed by other authors."

An interesting aspect of the BOS concept is that it scores very high on the buzzword meter. According to Cluley (2013), buzzwords may have multiple functions in organizations: (1) claiming authority; (2) facilitating actions; and (3) displacing responsibility. First, BOS can be used to claim authority in different ways. Managers can talk about BOS to claim authority and show that they are well-read when it comes to the latest strategy-related theory and discourse.

The invocation of BOS-related rhetoric (the use of words such as disruption, innovation, market spaces and agility) also signals that the organization is modern and what Abrahamson (1996, p. 267) calls "at the forefront of managerial progress." Arguably, the BOS concept calls to mind images of innovativeness, strategic agility and profits.

Second, the BOS concept may be useful in facilitating organizational and strategic change, and driving change projects. The red versus blue ocean metaphor is powerful, and conventional market spaces where most organizations operate are referred to as shark-infested "oceans of blood." For organizations that struggle to survive within traditional market spaces, it becomes easier to argue that radical strategic shifts and organizational changes are necessary in order to escape blood-thirsty sharks and seek out "blue oceans". BOS may help create a "sense of urgency" which is often needed to succeed with organizational changes (Kotter 1996).

Third, managers can utilize the BOS concept and rhetoric to argue that it is not really their decision. By enrolling the help of BOS consultants, they may shift responsibility for key decisions about strategic and organizational changes onto BOS consultants with expert powers. 


\subsubsection{Performance Enhancements}

In the literature on management concepts and ideas, several authors emphasize that promises of performance improvements is an important characteristic for a concept to become popular and widely diffused (Benders and Van Veen 2001; Huczynski 1992; Røvik 2002). This is to a large degree because managers are unlikely to become interested in adopting a new concept if they do not perceive that there may be potential benefits of adoption, or alternatively fear being at a competitive disadvantage in case of non-adoption (Benders 1999; Kieser 1997).

BOS is an idea that belongs to what Mol et al. (2017, p. 2) refer to as "the domain of practitioner-oriented management ideas about the sources of success." Since the concept of BOS at the core is a recipe for how to become successful, the claims of potential performance improvements are generally very strong.

In the books about BOS, the authors suggest that the concept could lead to substantial performance improvements. For example, Kim and Mauborgne (2005b, p. 9) suggest that BOS is superior to other management ideas such as those presented in earlier management bestsellers such as Built to Last (Collins and Porras 2005) and In Search of Excellence (Peters and Waterman 1982). Hence, it can be argued that KM use a strategy where they try to discredit and undermine other similar management ideas. This is, however, a common strategy used by proponents of management ideas, which previously has been observed in context of competing management idea movements such as Benchmarking and Business Process Reengineering (Longbottom 2000; Madsen et al. 2017).

KM largely draw on case studies and anecdotal evidence to back up their claims about the performance increasing effects of using the BOS concept. To this point, critics may argue that there is a selection bias in the choice of case examples, and that the BOS framework is mainly used as a lens through which these earlier success stories are interpreted. There is generally less in terms of large-scale quantitative evidence to back up their claims. It should be noted that Kim and Mauborgne (2005b, p. 8) admit the limitations of their data: "Although we don't have data on the hit rate of success of red and blue ocean initiatives, the global performance differences between them are marked."

\subsubsection{Interpretive Space}

An important characteristic of management concepts is that they are formulated in a relatively ambiguous and vague way, which means that the concepts lend themselves to a multitude of interpretations and translations in practice. Researchers call this the "interpretive viability" (Benders and Van Veen 2001) or "interpretive space" (T. Clark 2004b) of management concepts.

When looking at the case of BOS, it becomes clear that the concept has considerable room for interpretation on the part of the actors drawing on and applying the concept in practice. For example, some researchers have noted that BOS is not a very theoretically coherent concept (Kociatkiewicz and Kostera 2016) and lacks a "scientific theoretical corpus" (Aspara et al. 2008). As Kociatkiewicz and Kostera (2016) point out, it is written in an entertaining way as a series of loosely connected success stories. Therefore, it can be argued that the book, similar to other management guru texts, appeals more to managers' emotions and subjective interpretations than to sound scientific logic and argumentation (cf. Nørreklit 2003).

It can be argued that the concept of BOS has considerable room for interpretation. The vagueness and ambiguity of the concept means that it can be interpreted in different ways by different readers who actively has to create meaning around BOS. Since there is much room for interpretation, the reader may end up with his own BOS theory rather than the one presented and intended by the concept's creators (cf. Nørreklit 2003). Moreover, the developments in KM's concept literature means that the interpretations made by users will vary depending on which book or article they read. 


\subsubsection{Universality}

Finally, popular management concepts and ideas tend to be presented as being universal in nature, decontextualized from the particularities of an individual organization (Huczynski 1992; Lillrank 1995, 2015; Røvik 1998). As noted by Wittrock (2015), management concepts are often presented as context independent.

In the case of BOS, it is clear that KM claim universal applicability of their BOS framework. Dixit (2014, p. 1132) observes that the concept of BOS is presented by advisors/writers as a "universally valid nostrum." For example, in an interview, KM state that "Blue ocean strategy is applicable across all types of industries from typical consumer product goods to b2b" (Leavy 2005, p. 20). Hence, BOS is presented as useful for organizations across the board, for private sector firms (e.g., Nintendo or Cirque de Soleil) to non-profits and public sector organizations.

The worldwide popularity and acceptance of BOS is another indication that the concept is presented in a way that is appealing across institutional and cultural contexts. For example, the BOS books have been translated to multiple languages and have won numerous awards and accolades in non-Western economies such as China, Russia and Vietnam.

\subsection{Evaluation of the Potential of BOS as a Management Fashion}

The analysis in the previous section shows that BOS exhibits several of the characteristics of popular management concepts identified in previous research (Benders and Van Veen 2001; Huczynski 1992; Røvik 2002). In many ways, BOS follows the "winning formula" and contains the "secret sauce" needed to flow widely and succeed in the global market for management concepts and ideas.

However, as it is noted in the literature on management concepts and ideas, it is not a given that a concept with a high fashion potential actually becomes fashionable. For example, a concept needs to reach a critical mass of followers before bandwagon effects kick in (Benders 1999). For a concept to "take off," it needs the support of supply-side actors who are able to create awareness and gin up interest among potential adopters of the concept. Over time, this will entice new supply-side actors (e.g., consultants) to jump on the bandwagon and create concept-specific products and services. Such complementary products and services will help in the implementation and application of the concept and increase the likelihood that the fashion will become institutionalized as an organizational practice (Klincewicz 2006; Perkmann and Spicer 2008).

\section{The Supply-Side of BOS}

This section examines the supply-side of BOS, i.e., the field of actors involved in the promotion and popularization of the concept in the field of strategy and management practice. According to the management fashion perspective, this field of supply-side actors is referred to as the "fashion-setting community" (Abrahamson 1996) or "management fashion arena" (Jung and Kieser 2012). In previous research, it has been suggested that the field of strategy is populated by various fashion-setting actors such as, for instance, strategy consultants, gurus and professors (T. Clark 2004a). These actors play key roles in shaping the diffusion and institutionalization of new strategy concepts and tools (Jarzabkowski and Kaplan 2015). In the following, we will examine in more detail the roles and activities of the various types of actors which we deem to have been of particular importance in the emergence and evolution of BOS.

\subsection{Management Gurus}

Management gurus play important roles in the introduction and legitimization of new management concepts and ideas (Huczynski 1993; Jackson 2001). Huczynski (1993) distinguishes between different types of management gurus: consulting gurus, academic gurus and hero managers. In the case of BOS, KM have assumed the role of academic gurus and have been the primary driving 
force spearheading the popularization of the concept. It is difficult to identify any other gurus who have been closely associated with the BOS concept, at least at the international level. It is, however, possible that there are "lesser" gurus associated with BOS in different countries around the world, as this has been seen in the cases of other management concepts (Fincham and Evans 1999; Madsen and Slåtten 2013).

As described previously, the concept of BOS was developed and coined by KM. KM quickly ascended to business celebrities in the wake of the enormous success of the first BOS book in 2005. It could be argued that they can be considered both "academic gurus" and "celebrity professors" playing in the same league as for instance Michael Porter of the Harvard Business School. For example, in recent years, KM have consistently ranked in the top 5 of management thinkers by the website Thinkers50.com. ${ }^{2}$

Clark et al. (2012) point out that management gurus may become celebrity consultants, and a similar development can be seen in the case of KM. Over the course of the last decade or so, it appears that the duo has used BOS as a spring board to create a range of products and services related to the implementation of BOS in organizations around the world (e.g., management consulting services, speaking engagements and certifications).

\subsection{Business Schools}

Business schools play an important role in the diffusion and institutionalization of management concepts and ideas (Sahlin-Andersson and Engwall 2002). For example, some popular concepts and ideas spring out of research undertaken by business school professors. In other cases, business professors may pick up on new developments in practice and theorize these ideas further in case studies or textbooks. Moreover, by incorporating new concepts and ideas in educational programs and curricula, business schools legitimize new concepts and ideas, and give them an academic stamp of approval. As will be discussed, it is possible to identify several examples of such processes taking place in the case of BOS. We will first take a look at the central roles of INSEAD and Harvard Business School in the popularization of BOS, before examining the level of interest in BOS by the wider academic community.

\subsubsection{INSEAD and Harvard Business School}

First, we will examine the role played by INSEAD and Harvard Business School, two business schools that usually are found near the top of the rankings of schools in the global business education market (Collet and Vives 2013). In the case of BOS, these two high-status business schools have been closely associated with the concept (Gandellini and Venanzi 2011). Researchers have suggested that the "prestige of the sponsoring business schools" can explain some of the concept's attention-grabbing qualities and popularity (Gandellini and Venanzi 2011, p. 4).

In particular, INSEAD has been important as the epicenter and intellectual home of the BOS movement. After all, KM are both senior INSEAD professors. Over time, BOS has become an integral part of the various management education programs offered by INSEAD, and the BOS concept is covered in courses at different levels (e.g., MBA, Executive Programs).

There are numerous BOS-related courses at INSEAD offered at different levels (e.g., MBA, Open Enrolment, Company Specific Programmes). ${ }^{3}$ One example at the executive education level is the INSEAD Blue Ocean Strategy Programme. ${ }^{4}$ Overall, the BOS courses appear to be financially lucrative since the price tags for some shorter executive education courses are about 7500 Euros. ${ }^{5}$

\footnotetext{
http:/ / thinkers50.com/biographies/w-chan-kim-renee-mauborgne/.

https:/ / centres.insead.edu/blue-ocean-strategy/courses/index.cfm.

https: / / www.youtube.com/watch?v=tHrczZvTjaG8.

https: / / execed.economist.com/insead-blue-ocean-strategy-2018-05-29.
} 
Based on an examination of INSEAD's website, it is clear that the school is generally supportive of BOS. It appears that INSEAD uses the BOS concept as an "organizing framework" around which the school has built many of the courses in its executive education programs.

Harvard Business School has also been one of the sponsoring business schools. The BOS literature has been published in the Harvard Business Review and by Harvard Business Publishing. In addition, BOS cases are for sale via its website. The value of being associated with Harvard cannot easily be overstated, since Harvard Business School case materials are used in business schools around the world, in particular in schools that subscribe to the case-based method of teaching.

It is not an easy task to assess the impact of BOS on other business schools around the world. However, BOS cases are for sale via The Case Center, ${ }^{6}$ which is an organization dedicated to "advancing the case method." A search for "W Chan Kim" on The Case Center website results in 122 different products for sale. In 2017, KM were in 8th place on the list of bestselling case authors. ${ }^{7}$ This is arguably a strong indication that the BOS cases are widely used in business schools around the world.

\subsubsection{Academic Interest}

Despite the high level of interest among practitioners and the attention showered on the concept in the popular business press, it has been noted that BOS has received relatively little attention in academic circles (Parvinen et al. 2011).

To investigate this further, we carried out searches for the term "Blue Ocean Strategy" in the Scopus and ScienceDirect databases. Although Figures 1 and 2 both show a similar pattern, with a steady growth in the number of academic publications, the total volume of publications can be considered relatively low compared to other management concepts. For example, in 2014 there was nearly 400 hits for the term "SWOT Analysis" in the ScienceDirect database (Madsen 2016b), whereas the search for "Blue Ocean Strategy" resulted in only 15 hits. Therefore, the observation that BOS has received relatively little attention in academic research is supported.

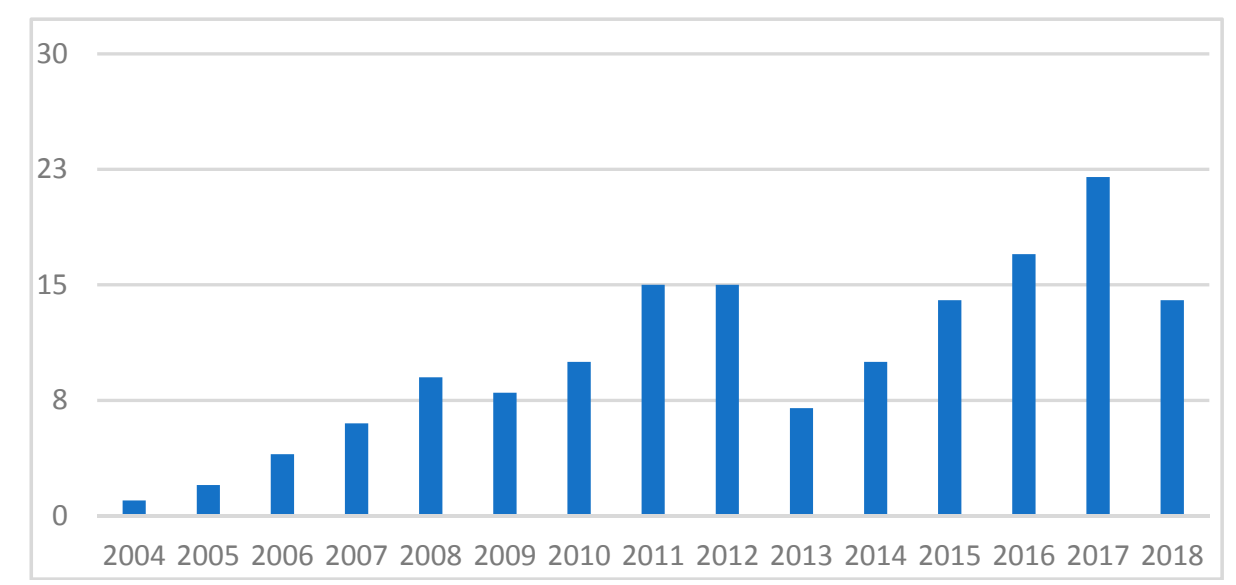

Figure 1. Hits for the search term "Blue Ocean Strategy" in the Scopus database (www.scopus.com), per 20 December 2018.

6 https://www.thecasecentre.org/educators/ordering/selecting/featuredcases/blueoceanstrategy\&.

7 https://www.thecasecentre.org/educators/casemethod/bestsellingauthors/2017/intro/. 


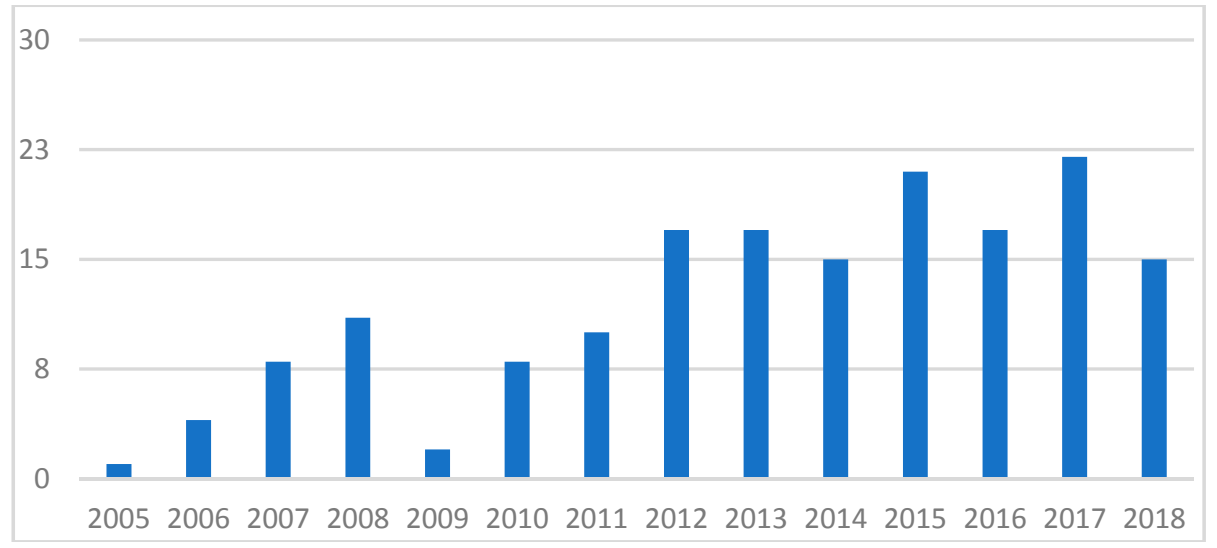

Figure 2. Hits for the search term "Blue Ocean Strategy" in the ScienceDirect database (www. sciencedirect.com), per 27 December 2018.

Furthermore, we carried out a superficial review of the articles listed in Scopus. It appears that many articles are published in journals with an explicit practitioner-oriented focus (e.g., Strategy and Leadership) and relatively few are published in more theory-heavy outlets, which may be the most prestigious journals among researchers in the strategy research community. What may explain this relative neglect of BOS? There are many possible reasons for the relative neglect of BOS in the academic research literature. For example, it is possible that the concept is viewed by some strategy researchers with a degree of skepticism and disdain. In the next subsection we will take a look at some of the criticism leveled at the concept by academics.

\subsubsection{Academic Criticism}

Some of the strongest critics of BOS can be found in the academic community. BOS has been called a «popular non-scholarly concept» (Hilb and Casas 2015), and has been criticized for lacking theoretical coherence (Kociatkiewicz and Kostera 2016) and a "scientific theoretical corpus" (Aspara et al. 2008). Others note that the concept of BOS suffers from a selection bias since KM write about success stories in retrospect (Tassabehii and Isherwood 2014). Finally, some researchers argue that the explanatory model is perhaps too simplistic. To this point, Dixit (2014, p. 1132) points out that BOS is an example of a "magic-bullet single solution." In a similar vein, Mol et al. (2017) note that BOS, like many other practitioner-oriented management ideas, is basically a "single-factor explanation" of what makes a company successful.

\subsection{Consulting Firms}

Consulting firms are usually heavily involved in the diffusion and institutionalization of new management concepts and ideas (Heusinkveld and Benders 2012; Heusinkveld 2013). This is also the case in the strategy field where consulting firms (e.g., McKinsey, BCG and Bain) are key actors and suppliers of new concepts and ideas (T. Clark 2004a; Jarzabkowski and Kaplan 2015). In the case of BOS, several of the larger generalist consulting firms have included BOS in their service repertoires.

In addition, there are several specialist consultancies focusing on BOS. One example of a specialist firm is Strategize Blue (www.strategizeblue.com) which offers "blue ocean consulting" and "blue ocean training." This firm self-identifies as "blue ocean strategists" and highlights that it is certified. Similarly, The Change Agent Group (www.changeagentgroup.com) also focuses on BOS $^{8}$ and uses as a selling point the fact that it holds Blue Ocean certifications and is part of a global network of BOS experts.

8 http://www.changeagentgroup.com/blueoceanstrategy.html. 


\subsection{Training, Certifications and Awards}

In the aftermath of the early success with BOS, KM started the INSEAD Blue Ocean Strategy Institute in 2007. On the website, this organization describes itself as "the academic hub of the blue ocean strategy global community." Thus, it functions as a network hub connecting users to consulting services and training workshops related to the use of the concept in practice in different countries around the world. KM have also launched the Blue Ocean Global Network (BOGN) which offers products such as the Blue Ocean AcademyTM and Blue Ocean StudioTM. These products are mostly online tools which help in learning about, developing and implementing BOS. Another provider of BOS training is the Blue Ocean Academy (www.blueoceanacademy.com).

Many of the training courses related to BOS appear to be quite expensive, which could be interpreted as an indication of the current demand for and popularity of the ideas. Most of the time, the prices of courses are not listed on the official websites. However, for some of the courses, the price tags are listed. For example, a 3-day training course in London costs 1990 GBP. ${ }^{9}$

Certifications is another way for suppliers to legitimize and institutionalize new management concepts and ideas (Perkmann and Spicer 2008). For example, INSEAD has been involved in the provision of certifications, by offering a Blue Ocean Strategy Certificate. ${ }^{10}$ Another certification is called "Certified Blue Ocean Practitioner". In general, the trend towards formalized training and certifications indicates a professionalization of the field around BOS. The practitioners who attend training and obtain certifications develop a vested interest in the continued popularity and institutionalization of the BOS concept. After all, certifications etc. related to BOS would lose most of their value on a resume if the concept falls out of fashion and/or is discredited due to poor implementation results/experiences.

Finally, an interesting development in recent years has been the introduction of awards to current users of BOS, e.g., The Annual Blue Ocean Awards (https://blue-awards.com/). The introduction of awards has been seen in several other management concept movements such as the Balanced Scorecard ("Balanced Scorecard Hall of Fame") and Total Quality Management ("Malcolm Baldrige National Quality Award").

\subsection{Conventional Business Media}

Conventional business media are thought to be a key channel in the diffusion of knowledge about new concepts and ideas (Alvarez 1998; Sahlin-Andersson and Engwall 2002). Conventional business media include business newspapers, management books, as well as magazines. Traditionally, management books (e.g., practitioner-oriented management literature) have been considered perhaps the most important channel for the dissemination of management knowledge (Røvik 2002).

In the case of BOS, business media appear to have been influential in the popularization of the concept. For instance, the prestigious book publisher Harvard Business Publishing has stood behind the official BOS books. The importance of the books by KM in the popularization of BOS cannot easily be overstated. As mentioned previously, the original BOS book by Kim and Mauborgne (2005b) has become a worldwide bestseller and has been translated to numerous languages. In addition, the book has received many positive reviews and accolades from influential business magazines such as Forbes and BusinessWeek.

\subsection{Social Media}

There are indications that some of the discourse around management concepts and ideas is increasingly taking place online via blogs and different social media platforms such as LinkedIn, YouTube, Twitter, and Facebook (Madsen and Slåtten 2015a). In the case of BOS, there is considerable

9 https://courses.independent.co.uk/training/boc-global-events-training-group/blue-ocean-strategy-408301.

10 https://centres.insead.edu/blue-ocean-strategy/courses/certificate.cfm. 
evidence of promotional activities related to BOS via websites (www.blueoceanstrategy.com) and various social media platforms. For example, there is much BOS-related discourse on Twitter. ${ }^{11}$

\subsection{Conferences and Seminars}

Conferences and seminars is another key channel through which management concepts and ideas are diffused (Jung and Kieser 2012). At these conferences, suppliers present new concepts and ideas, and network with and build ties to potential consumers.

KM's Blue Ocean Strategy Network (https:/ / www.blueoceanstrategy.com/network/) appears to offer different types of BOS workshops and seminars. Web searches also reveal that in recent years there have been a number of different conferences around the world with BOS as an overarching theme. For example, "International Conference on Blue Ocean Strategy" in Asia" ${ }^{12}$ and the "Blue Ocean Strategy Conference" in Canada which featured Kim as a presenter. ${ }^{13}$

\subsection{Evaluation}

This section has examined the supply-side of BOS. Overall, the findings suggest that the configuration of the supply-side is dominated by the concept's founders KM. The duo has had a central boundary-spanning role and have, to a large extent, managed to stay in control of the concept's evolution. Moreover, they have professionalized the field around BOS by certifying "Blue Ocean Consultants" and "Blue Ocean Strategists" who in turn develop a vested interest in the continued popularity of the concept. Business schools closely associated with KM have also played a key role in driving the popularization and institutionalization of BOS. In particular, KM's employer INSEAD as well as Harvard Business School have incorporated the BOS concept in various educational programs and materials.

\section{The Demand-Side of BOS}

In this section the focus shifts to the concept's demand-side. This involves examining the take-up and application of the concept by organizations and managers. Assessing the demand-side's use of popular management concepts is far from an easy task and it may be necessary to combine different data sources to get a window into a concept's impact on organizational practice (Benders and Van Veen 2001). In this paper, the impact of BOS will be assessed by looking at (1) awareness and interest; (2) adoption and diffusion; (3) implementation; and (4) effects.

\subsection{Awareness and Interest}

First, we will take a look at the awareness and interest in the BOS concept among organizations and managers on the demand-side. The level of awareness provides an indication about the potential adoption and diffusion of a management concept (Madsen 2016a). Therefore, for suppliers of new concepts, it is of critical importance to disseminate information to the adopter market. Just like when consumers are evaluating product choices, a management concept has to be among a manager's "evoked set" (Narayana and Markin 1975) during the process of evaluating management concept choices.

In general, there are few studies that have explored the level of knowledge and awareness of BOS in organizational practice. One exception is the recent study by Tassabehji and Isherwood (2014) where it was found that the knowledge about BOS was low in practice and that only about 40 percent had heard of the concept.

11 https://twitter.com/blueoceanstrtgy?lang=enorhttps://twitter.com/blueawards?ref_src=twsrc\%5Etfw.

12 https://www.nst.com.my/news/2016/08/165517/leaders-arrive-international-conference-blue-ocean-strategy.

13 http://www.drakeintl.com/localjobs/testing/event.html. 
Another way of assessing managerial interest in BOS is to utilize Internet search data. In previous research it has been suggested that search behavior may say something about the interest in a concept (Madsen 2016a). While Google Trends only contains data from 2004 and onwards, this is not a problem in the case of BOS since the term was not introduced until the mid-2000s (Kim and Mauborgne 2004, 2005b).

Our search for the term "Blue Ocean Strategy" (Figure 3) reveals that there was some activity in 2004 but that the interest picked up quickly and reached a peak in the mid to late 2000s. The rest of the Google Trends curve follows a downward-sloping pattern. There are several possible explanations for the decrease in search interest. One explanation could be related to a lower level of newsworthiness of BOS. For example, it could be that managers nowadays are interested in learning about (even) newer concepts such as, for example, Big Data Analytics and Internet of Things. A second explanation is that there is less of a need to "Google" management concepts as they become well-known and established in managerial education and practice (Madsen 2016a). This could well be the case for BOS, since the concept has become part of the standard vocabulary in the field of strategy and management (Birkinshaw and Mark 2017; Low and Ang 2013; Mi 2015).

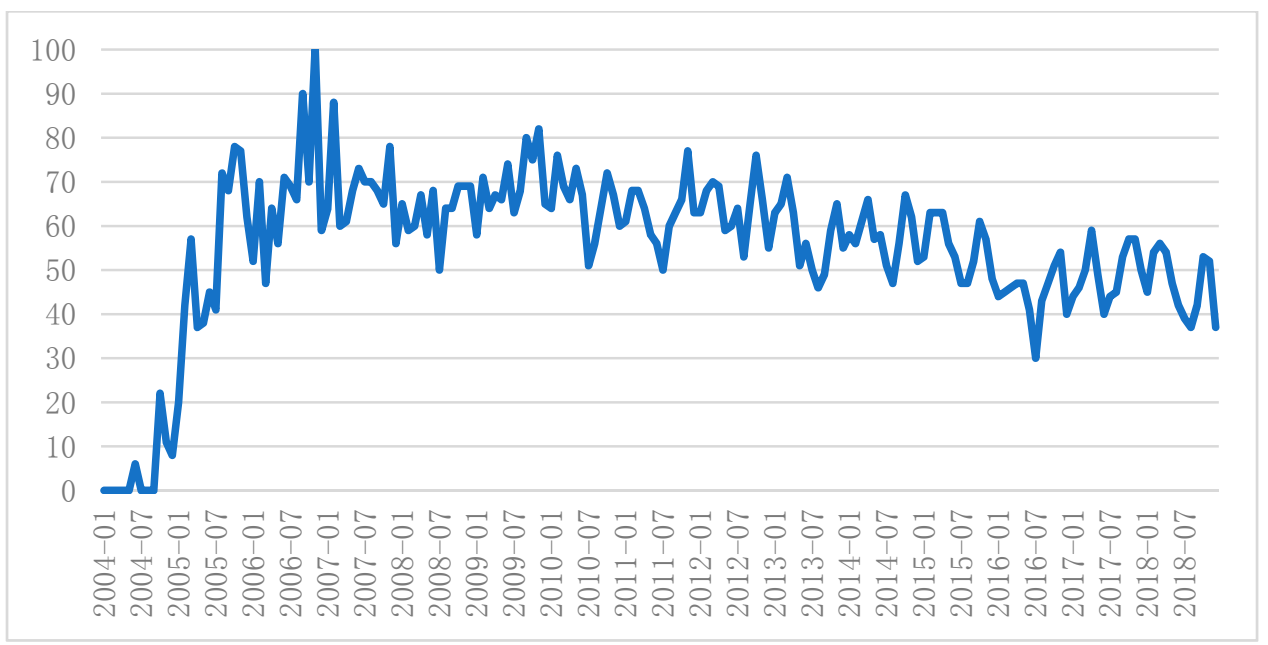

Figure 3. Google Trends curve for the term "Blue Ocean Strategy" (Data source: www.google.com/ trends, accessed 22 October 2018).

\subsection{Adoption and Diffusion}

The previous sections have shown that BOS has attracted significant attention and interest in recent years. There appears to be much appetite and demand for expensive training programs, workshops and consulting services related to BOS. After all, somebody out there is buying the millions of BOS books. These are all possible indications that the BOS concept may be widely used by organizations on the demand-side.

However, as it has been pointed out in the literature on management fashions, the discourse about a management concept on the supply-side and its actual usage on the demand-side does not necessarily coevolve (Nijholt and Benders 2007). For example, a concept may get much attention in public management discourse without being widely used by organizations. Conversely, a concept may be viewed as outdated and not very newsworthy, but may still be used by organizations. Therefore, in order to say something about the actual organizational impact of BOS, we still need to examine studies that have looked at the actual adoption and diffusion of the concept.

Bain and Company's "Management Tools and Trends Survey" suggests that BOS may not be as popular in organizational practice as others would have us believe. For example, BOS has yet to make its way into the top 25 ranking of management tools (Rigby 2017; Rigby and Bilodeau 2018). Aarrestad and Hem (2008) paint a different picture, citing a newspaper article suggesting that BOS in 
2006 was one of the 10 most used management tools in Chinese companies. However, it is less clear what types of data were used in this Chinese ranking of management tools.

Another relatively recent study found that the frequency of use of BOS was $20.5 \%$ (Tassabehji and Isherwood 2014). Tassabehji and Isherwood (2014) found that managers use a variety of strategy tools, and noted that managers "overwhelmingly continue to use those that are well established and focus on the management of internal and external resources, whereas tools aimed to foster more innovative, dynamic, and 'blue ocean' strategies are not widely applied in practice" (p. 63).

In general, there are few larger scale surveys which can be used to shed light on the adoption and diffusion of BOS around the world. However, the available studies of the adoption and diffusion suggest that the use of BOS on the demand-side is relatively limited. It appears that the hype surrounding BOS has not yet resulted in a very widespread adoption of the concept. This indicates the organizational impact of BOS does not fully mirror the huge book sales.

\subsection{Implementation}

Relatively little is known about how BOS is implemented in organizations. However, studies suggest that the concept is being applied in a variety of different contexts. In recent years, dispersed studies have looked at, for instance, the use of BOS in the context of start-ups (Širec and Močnik 2016), performance evaluation (Tabari et al. 2014), new product development (Pitta 2009), the business-to-business sector (Čirjevskis et al. 2011), the daily industry (Amini and Saravi-Moghadam 2017), and in the medical field (Kamal and Dionne-Odom 2016; Slocum and Papa 2014).

While the BOS books offer case examples and success stories (e.g., several case examples and anecdotes from well-known US companies such as Cirque du Soleil, Southwest Airlines, and Home Depot), in the scholarly strategy literature detailed case studies are few and far between (Becker 2014, 2018).

However, studies suggest that the implementation of BOS can be challenging, for instance in terms of the time involved. For example, one article discusses how to "incubate" BOS initiatives, which suggests that the implementation of BOS is not something that can be done overnight, and that organizational and managerial preparation is a key success factor (Leavy 2018).

Some studies also suggest that BOS is implemented in different ways. For example, there are variations of the BOS framework which use new terms such as green, purple and black ocean strategies (Aithal 2016). BOS is also often used in combination with existing and traditional competitive strategy concepts such as Five Forces (Burke et al. 2010; Burke et al. 2009). Recently, BOS has been combined with other popular contemporary management concepts and ideas such as Agile (Denning 2017b) and Lean sustainability (Loh et al. 2018).

There is also a tendency for BOS to be used at different analytical levels in practice. For example, the Malaysian government has introduced a "National Blue Ocean Strategy" (Ramli et al. 2016). At the personal level, the BOS concept has been used to formulate "A Blue Ocean way of getting into shape" (Srinivas 2015). Here we can observe a development similar to what has seen in the case of the SWOT Analysis framework, which has morphed from being a concept primarily used at the organizational level to a broader concept which is applied across different levels of the social context (Madsen 2016b).

\subsection{Effects}

What are the performance effects of adopting and implementing BOS? As noted in Section 2, proponents of BOS typically claim that BOS is a universally applicable concept that can potentially lead to great performance improvements for all types of organizations. The evidence offered by BOS proponents such as KM is mostly case-based and anecdotal in nature. However, as discussed, there are relatively few studies which have looked at the performance effects of implementing the concept. As Parvinen et al. (2011, p. 1219) note, there have been few attempts to test BOS and, as a result, there is a general lack of empirical evidence. In order words, there has been little "due diligence" of the strong claims of performance improvements made by KM in the BOS literature. 
However, there are some studies which suggest that the use of BOS could have beneficial effects on organizational and strategic processes. A study comparing BOS and the Five Forces framework found that BOS-inspired strategies could be beneficial for companies in the long term, while Porterian strategies could be beneficial for companies in the short run (Burke et al. 2010, 2009). Moreover, a study of more than 500 users of BOS in Finland found that BOS was an "advantage in the profitable growth of their sales activities" (Aspara et al. 2008). In the words of Aspara et al. (2008, p. 8), "companies creating new market opportunities by utilizing blue ocean strategies in their business model transformation were found to have an advantage in the profitable growth of their sales activities."

That said, researchers have also identified possible negative effects associated with BOS implementation. For example, there are challenges associated with implementing BOS strategies. As Hollensen (2013) points out, blue oceans may quickly turn red, which means that managers have to be dynamic and continuously reformulate their strategies.

\section{Discussion}

In this section we will discuss the current article's findings in relation to the literature on fashionable management concepts and ideas. The discussion revolves around three broad themes: the BOS concept's (1) emergence; (2) evolution; and (3) lifecycle and popularity trajectory.

\subsection{Emergence}

First, we will discuss the emergence of BOS as a concept in the field of strategy. As was shown earlier, the importance of the concept's creators KM cannot easily be overstated. The concept has been spearheaded by KM, two high-status, celebrity business school professors. The duo has rather successfully leveraged their business school networks in the popularization and legitimization of the concept. KM's employer INSEAD has had a particularly influential role as the epicenter and "intellectual home" of the BOS concept. However, BOS has also benefited from the connection to the network around Harvard Business School. As was noted previously, BOS was introduced by KM in a Harvard Business Review article (Kim and Mauborgne 2004), and about a year later the concept was fleshed out in a book published by the Harvard Business School Press (Kim and Mauborgne 2005b).

In this way, the emergence of BOS bears similarities with the pattern seen in the cases of other contemporary management concepts, which have also been closely associated with high-ranking business schools. For example, Business Process Reengineering is associated with Michael Hammer and MIT (Hammer and Champy 1993). In HR field, the guru Dave Ulrich (Ulrich 1998) is associated with University of Michigan-Ross School of Business. In the cases of Robert Kaplan's Balanced Scorecard (BSC) and Activity Based Costing (ABC), Harvard Business School can be considered the intellectual home.

The latter two concepts are particularly interesting to discuss in the context of the emergence of BOS. Both the BSC and ABC concepts were launched through Harvard-affiliated publications. For example, Jones and Dugdale (2002) showed the role that the network around Harvard Business School played in the popularization of ABC. Similarly, the BSC was launched and popularized via a Harvard Business Review article and developed further in a string of follow-up books and articles (Cooper et al. 2017). In both of these cases, well-connected and high-status academics played a key role in the popularization process (Cooper et al. 2017; Jones and Dugdale 2002).

\subsection{Evolution}

Second, we turn to a discussion of the conceptual evolution of BOS. As noted in Section 2, the BOS concept has evolved as a result of several follow-up articles (e.g., Kim and Mauborgne 2009, 2014, 2015a), an expanded version of the first book (Kim and Mauborgne 2015b), and most recently, in the new book "Blue Ocean Shift" (Kim and Mauborgne 2017b).

One interesting observation in relation to the evolutionary pattern of BOS is that the concept's originators KM to a very high degree have been able to keep control of the concept. KM have 
accomplished this by building a network of affiliates around the world and by using certifications to exert influence over other consultants and trainers who have sought to offer BOS services. In other words, KM have exhibited strong leadership of the movement around BOS.

It is possible that KM have learned from the experiences of other earlier movements, such as the BSC movement led by Kaplan and Norton. In the case of the BSC movement, Kaplan and Norton, did manage to keep at least some degree of control over BSC consulting services via their consulting organization, and certified official software as well as provided training. However, in a recent article they note that keeping control of the concept can be challenging as many other consulting firms attempted to latch on to the BSC movement and create their own versions of the BSC concept (Kaplan et al. 2018).

There are also some similarities between the two duos KM and Kaplan and Norton when it comes to work ethic, energy and enthusiasm. Some years ago, The Economist referred to the duo Kaplan and Norton "the most inseparable double-act in management" (The Economist 2009). Over a period stretching more than 25 years, Kaplan and Norton have produced a steady stream of books, articles, cases, and conference presentations about the Balanced Scorecard, keeping the concept up-to-date and at the forefront of managerial attention (Cooper et al. 2017). Similarly, KM have also stayed together as an energetic and charismatic duo fronting BOS in different arenas around the world and disseminating the concept via books, articles, workshops, and training programs.

$\mathrm{KM}$ can also be seen as fashion-setting actors who have utilized a BOS-type of strategy in their efforts to disseminate and popularize the BOS concept. Instead of going up against the red ocean of existing and established concepts and frameworks on strategy and strategic planning (e.g., the frameworks developed by Michael Porter, Jay Barney, and others), they have sought to create a blue ocean in the field of strategy. They have created a relatively uncontested market space (blue ocean) for themselves by building on, repackaging and rebranding many existing ideas in the strategy literature, and by linking them to newer ideas which fit well with the zeitgeist of the first decade of the 21st century, such as disruptive innovation, business model innovation and strategic agility. In this sense, the KM have "walked the talk" by actually utilizing some of the prescriptions of the BOS approach to popularize their own concept and create a BOS movement. They have also managed to keep the blue ocean from turning red, by keeping control of the concept through activities such as certification and affiliation strategies.

\subsection{Life Cycle and Popularity Trajectory}

Third, we will discuss the lifecycle and popularity trajectory of BOS. It is evident that BOS is a relatively nascent phenomenon in the field of strategy. However, its popularity in public management discourse has been on an upward trajectory since the concept's inception in the mid-2000s. The massive book sales suggest a level of popularity seldom seen in field of strategy and management. It is relatively safe to assert that BOS currently takes up a large share of the public management discourse related to strategy. This means that BOS, according to the definition provided by Jung and Kieser (2012, p. 329), currently can be considered a management fashion. However, what actual impact the BOS fashion has had on the demand-side of the market is less clear. As Section 5 showed, research on the usage of BOS is fragmented and does not provide a full picture.

While BOS has received much attention and support from important actors and institutions such as Harvard Business School and INSEAD, not everybody has acted as cheerleaders and fans of the concept. Over time, BOS has also been the subject of much criticism. Despite having been launched and popularized by two business school professors working at INSEAD, BOS has been viewed with a level of disdain by other academics. For example, the concept has been criticized for being popularized and non-scholarly (Hilb and Casas 2015), lacking scientific basis (Aspara et al. 2008), having low theoretical coherence (e.g., Kociatkiewicz and Kostera 2016) and being a single-factor explanation of company success (Mol et al. 2017). 
However, it is not clear to what extent the criticism has reached managers and other users of the concept. As research has shown in the case of the BSC, practitioners tend not to be aware of criticism published in academic journals (Madsen 2011). Therefore, it is far from clear whether this criticism will impact the future popularity of the BOS concept. It could be more dangerous for the BOS concept if the criticism originates from strategy practitioners with more "street cred" than theory-focused academics who tend to publish in scholarly strategy journals.

\section{Conclusions}

\subsection{Contributions}

\subsubsection{Theoretical Contributions}

In this paper we have examined BOS through the lens of management fashion theory. While there have been some previous academic critiques of different aspects of BOS, the concept has received relatively little scholarly attention. To the best of our knowledge, this study has been the first to examine BOS from the vantage point of management fashion theory. Due to the enormous popularity of the BOS books and articles, the time was, in our view, ripe for such an examination.

Overall, our case study of the emergence and evolution of BOS suggests that the popularity trajectory of BOS diverges in some respects from what has been seen in studies of other fashionable management concepts and ideas. In particular, our study indicates that BOS is an example of an academic-guru-led movement. KM have, rather successfully, used their positions and legitimacy as celebrity business school professors to stay in the driver's seat and keep close control of the development and evolution of the concept using different activities and strategies such as networking, certification, and the creation of a wide range of complementary products and services.

However, based on our review, it appears that BOS has not had as large of an impact on organizational practice as would be expected based on the concept's share of public management discourse (e.g., huge book sales). Thus, the current study provides some support for the view that supply-side and demand-side activity related to management fashions does not necessarily coevolve (Nijholt and Benders 2007).

\subsubsection{Practical Contributions}

The practical contributions of a study using the fashion lens may at first sight be less obvious. However, the findings may be useful for practitioners in the field of strategy.

For managers who are considering adopting and implementing BOS, the paper provides a broad overview of the historical background and evolution of BOS, as well as an overview of various studies that provide insight into the general experiences with BOS implementation.

For management knowledge entrepreneurs, such as strategy consultants and gurus, who seek to introduce, popularize and keep control of new management concepts, the case of BOS could offer some valuable lessons. As discussed, KM have exerted much control over the evolution of BOS by directly or indirectly managing many of the activities, products and services. While this strategy may not be easy to replicate, it could serve as a good recipe for others wanting to succeed in the commercialization of new management concepts and ideas.

\subsection{Limitations and Further Research}

Like any piece of research, our paper is not without limitations. First of all, in this paper we have followed an exploratory and conceptual approach. While we have surveyed a wide range of sources to obtain a "picture" (Nijholt and Benders 2007) or "mosaic" (Morrison and Wensley 1991) of the emergence and evolution of BOS, it is difficult, if not impossible, to get a full picture. Furthermore, our paper is based on desk research, and we have not carried out any field research, for instance by 
interviewing experts with a longitudinal overview of the emergence and evolution of BOS, and of the strategy field, more generally.

Taking into account these limitations, there are several ways we think our exploratory research could be extended in the future. One area which stands out is the demand-side impact of BOS. Although the sales of the BOS books suggest that the concept currently is front and center in public management discourse, it is less clear the extent to which the concept has impacted actual organizational and strategic practice. As was shown in the review of extant studies, there is generally little evidence of BOS adoption and diffusion. Surveys of BOS carried out in different contexts (e.g., countries, sectors) could shed light on regional, national and/or sectorial variations in the diffusion and popularity of the concept (cf. Benders and Van Bijsterveld 2000). Such studies could help provide a fuller picture of the impact of BOS.

Another area that stands out is why the BOS book has become such a huge bestseller around the world. The success of this book in terms of sales lends support to the view that management literature is still important in the dissemination of management knowledge (Furusten 1999; Røvik 2002), even in the age of the Internet where public management discourse is increasingly shifting away from print-media towards social media platforms (Madsen and Slåtten 2015a). It would be interesting to find out more about who is buying all of the BOS books, as well as how and to what extent the books are actually read and consumed.

Author Contributions: The authors contributed equally and are listed alphabetically.

Funding: This research received no external funding.

Conflicts of Interest: The authors declare no conflict of interest.

\section{References}

Aarrestad, Inger Lise, and Leif Egil Hem. 2008. Ulike vekststrategier for et merke-En sammenligning (Del II). Magma-Tidsskrift for økonomi og ledelse. Available online: https:/ / www.magma.no/ulike-vekststrategierfor-et-merke-en-sammenligning-del-ii (accessed on 20 August 2018).

Abrahamson, Eric. 1996. Management Fashion. Academy of Management Review 21: 254-85. [CrossRef]

Abrahamson, Eric, Sungyong Chang, Yoonjin Choi, and Ivana Katic. 2015. Clashing Fashions and Institutions: Mid-Life Uncertainty in Innovation Diffusion. Available online: https: / / ssrn.com/abstract=2587558orhttp: / / dx.doi.org/10.2139/ssrn.2587558 (accessed on 20 August 2018).

Agnihotri, Arpita. 2016. Extending boundaries of Blue Ocean Strategy. Journal of Strategic Marketing 24: 519-28. [CrossRef]

Aithal, Sreeramana. 2016. The concept of Ideal Strategy and its realization using White Ocean Mixed Strategy. International Journal of Management Sciences and Business Research 5: 171-79.

Alvarez, José Luis. 1998. The Diffusion and Consumption of Business Knowledge. New York: St. Martin's Press.

Amini, Mohammad Taghi, and Nahid Saravi-Moghadam. 2017. Development of blue ocean strategy in dairy industry in Iran (evidence from Kalleh Company). International Journal of Management Concepts and Philosophy 10: 301-19. [CrossRef]

Aspara, Jaakko, Joel Hietanen, Petri Parvinen, and Henrikki Tikkanen. 2008. An exploratory empirical verification of blue ocean strategies: Findings from sales strategy. Paper presented at Eighth International Business Research Conference, Dubai, UAE, March 27-28.

Becker, Hilary. 2014. A Blue Ocean Strategy analysis of IMAX's move to go Hollywood. Journal of International Management Studies 14: 53-60. [CrossRef]

Becker, Hilary. 2018. Cirque du Soleil-Ka in Las Vegas: Sustainability of a Blue Ocean. Journal of International Management Studies 19. [CrossRef]

Benders, Jos. 1999. Tricks and Trucks? A Case Study of Organization Concepts at Work. International Journal of Human Resource Management 10: 624-37. [CrossRef]

Benders, Jos, and Mark Van Bijsterveld. 2000. Leaning on lean: The reception of management fashion in Germany. New Technology, Work and Employment 15: 50-64. [CrossRef] 
Benders, Jos, and Kees Van Veen. 2001. What's in a Fashion? Interpretative Viability and Management Fashions. Organization 8: 33-53. [CrossRef]

Benders, Jos, and Sander Verlaar. 2003. Lifting parts: Putting conceptual insights into practice. International Journal of Operations \& Production Management 23: 757-74.

Birkinshaw, Julian, and Ken Mark. 2015. Key MBA Models: The 60+ Models Every Manager and Business Student Needs to Know. London: Financial Times Publishing.

Birkinshaw, Julian, and Ken Mark. 2017. 25 Need-To-Know MBA Models. London: Financial Times Publishing.

Braam, Geert, Jos Benders, and Stefan Heusinkveld. 2007. The balanced scorecard in the Netherlands: An analysis of its evolution using print-media indicators. Journal of Organizational Change Management 20: 866-79. [CrossRef]

Burke, Andrew E., Andre J. Van Stel, and Roy Thurik. 2009. Blue ocean versus competitive strategy: Theory and evidence. ERIM Report Series Reference No. ERS-2009-030-ORG. Available online: https:/ /ssrn.com/ abstract=2024822 (accessed on 20 October 2018).

Burke, Andrew, André van Stel, and Roy Thurik. 2010. Blue ocean vs. five forces. Harvard Business Review 88: $28-29$.

Chesbrough, Henry. 2010. Business model innovation: Opportunities and barriers. Long Range Planning 43: $354-63$. [CrossRef]

Christensen, Clayton. 1997. The Innovator's Dilemma: When New Technologies Cause Great Firms to Fail. Boston: Harvard Business Review Press.

Christensen, Clayton M. 2006. The ongoing process of building a theory of disruption. Journal of Product Innovation Management 23: 39-55. [CrossRef]

Čirjevskis, Andrejs, Genadijs Homenko, and Valērija Lačinova. 2011. How to Implement Blue Ocean Strategy (BOS) in B2B Sector. Business, Management and Education 9: 201-15. [CrossRef]

Clark, Delwyn N. 1997. Strategic management tool usage: A comparative study. Strategic Change 6: 417-27. [CrossRef]

Clark, Timothy. 2004a. Strategy viewed from a management fashion perspective. European Management Review 1: 105-11. [CrossRef]

Clark, Timothy. 2004b. The fashion of management fashion: A surge too far? Organization 11: 297-306. [CrossRef]

Clark, Timothy, Pojanath Bhatanacharoen, and David Greatbatch. 2012. Management gurus as celebrity consultants. In The Oxford Handbook of Management Consulting. Edited by Matthias Kipping and Timothy Clark. New York: Oxford University Press, pp. 347-64.

Cluley, Robert. 2013. What Makes a Management Buzzword Buzz? Organization Studies 34: 33-43. [CrossRef]

Collet, François, and Luis Vives. 2013. From preeminence to prominence: The fall of US business schools and the rise of European and Asian business schools in the Financial Times Global MBA Rankings. Academy of Management Learning E Education 12: 540-63.

Collins, James Charles, and Jerry I. Porras. 2005. Built to Last: Successful Habits of Visionary Companies. New York: Random House.

Cooper, David J., Mahmoud Ezzamel, and Sandy Q. Qu. 2017. Popularizing a Management Accounting Idea: The Case of the Balanced Scorecard. Contemporary Accounting Research 34: 991-1025. [CrossRef]

Denning, Stephen. 2017a. Moving To Blue Ocean Strategy: A Five-Step Process to Make the Shift. Forbes, September 24.

Denning, Stephen. 2017b. The next frontier for Agile: Strategic management. Strategy E Leadership 45: 12-18.

Dixit, Avinash. 2014. Strategy in History and (versus?) in Economics: A Review of Lawrence Freedman's Strategy: A History. Journal of Economic Literature 52: 1119-34. [CrossRef]

Fincham, Robin, and Mark Evans. 1999. The consultants' offensive: Reengineering-From fad to technique. New Technology, Work and Employment 14: 32-44. [CrossRef]

Foss, Nicolai J., and Tina Saebi. 2017. Fifteen Years of Research on Business Model Innovation:How Far Have We Come, and Where Should We Go? Journal of Management 43: 200-27. [CrossRef]

Furusten, Staffan. 1999. Popular Management Books—How They Are Made and What They Mean for Organisations. London: Routledge.

Gandellini, Giorgio, and Daniela Venanzi. 2011. Purple Ocean Strategy: How to Support SMEs' Recovery. Procedia-Social and Behavioral Sciences 24: 1-15. [CrossRef]

Hamel, Gary, and Coimbatore Krishnarao Prahalad. 1994. Competing for the Future. Boston: Harvard Business School Press. 
Hammer, Michael, and James Champy. 1993. Reengineering the Corporation. New York: Harper Business.

Heusinkveld, Stefan. 2013. The Management Idea Factory: Innovation and Commodification in Management Consulting. New York: Routledge.

Heusinkveld, Stefan, and Jos Benders. 2012. Consultants and organization concepts. In The Oxford Handbook of Management Consulting. Edited by Matthias Kipping and Timothy Clark. New York: Oxford University Press, pp. 267-84.

Hilb, Michael, and Tomas Casas. 2015. Towards a construct of entrepreneurial strategising: The case of private equity. International Journal of Entrepreneurial Venturing 7: 84-101. [CrossRef]

Hill, Charles W. L., Melissa A. Schilling, and Gareth R. Jones. 2017. Strategic Management: Theory E Cases: An Integrated Approach. Boston: Cengage Learning.

Holiday, Ryan. 2017. Exclusive: The Authors of Blue Ocean Strategy Reveal How They Sold 4M Copies. Observer, September 26.

Hollensen, Svend. 2013. The Blue Ocean that disappeared-The case of Nintendo Wii. Journal of Business Strategy 34: 25-35. [CrossRef]

Huczynski, Andrzej A. 1992. Management Guru Ideas and the 12 Secrets of their Success. Leadership E Organization Development Journal 13: 15-20. [CrossRef]

Huczynski, Andrzej. 1993. Management Gurus: What Makes Them and How to Become One. London: Routledge.

Jackson, Brad. 2001. Management Gurus and Management Fashions. London: Routledge.

Jarzabkowski, Paula, and Sarah Kaplan. 2015. Strategy tools-in-use: A framework for understanding "technologies of rationality" in practice. Strategic Management Journal 36: 537-58. [CrossRef]

Johnson, Mark W. 2010. Seizing the White Space: Business Model Innovation for Growth and Renewal. Boston: Harvard Business Press.

Johnson, Gerry, Richard Whittington, Kevan Scholes, Duncan Angwin, and Patrick Regner. 2017. Exploring Corporate Strategy: Text \& Cases, 11th ed. London: Pearson Education.

Jones, T. Colwyn, and David Dugdale. 2002. The ABC bandwagon and the juggernaut of modernity. Accounting, Organizations and Society 27: 121-63. [CrossRef]

Jung, Nicole, and Alfred Kieser. 2012. Consultants in the Management Fashion Arena. In The Oxford Handbook of Management Consulting. Edited by Matthias Kipping and Timothy Clark. New York: Oxford University Press, pp. 327-46.

Kamal, Arif H., and J. Nicholas Dionne-Odom. 2016. A Blue ocean strategy for palliative care: Focus on family caregivers. Journal of Pain and Symptom Management 51: e1-e3. [CrossRef]

Kaplan, Robert Samuel, and David Norton. 2008. Execution Premium: Linking Strategy to Operations for Competitive Advantage. Boston: Harvard Business School Press.

Kaplan, Robert Samuel, Richard L. Nolan, and David Norton. 2018. The Creative Consulting Company. Harvard Business School Accounting \& Management Unit Working Paper No. 19-001. Available online: https: / / papers.ssrn.com/sol3/papers.cfm?abstract_id=3206642 (accessed on 20 November 2018).

Kieser, Alfred. 1997. Rhetoric and myth in management fashion. Organization 4: 49-74. [CrossRef]

Kim, W. Chan, and Renée Mauborgne. 1997. Value innovation: The strategic logic of high growth. Harvard Business Review, 103-12.

Kim, W. Chan, and Renée Mauborgne. 2004. Blue Ocean Strategy. Harvard Business Review 82: 76-84. [PubMed]

Kim, W. Chan, and Renée Mauborgne. 2005a. Value innovation: A leap into the blue ocean. Journal of Business Strategy 26: 22-28.

Kim, W. Chan, and Renée Mauborgne. 2005b. Blue Ocean Strategy: How to Create Uncontested Market Space and Make the Competition Irrelevant. Boston: Harvard Business School Press.

Kim, W. Chan, and Renée Mauborgne. 2009. How strategy shapes structure. Harvard Business Review 87: 72-80. [CrossRef]

Kim, W. Chan, and Renée Mauborgne. 2014. Blue ocean leadership: How to engage your employees and stop wasting everyone's time. Harvard Business Review 92: 60-72.

Kim, W. Chan, and Renée Mauborgne. 2015a. Red Ocean Traps. Harvard Business Review 93: 68-73.

Kim, W. Chan, and Renée Mauborgne. 2015b. Blue Ocean Strategy, Expanded Edition: How to Create Uncontested Market Space and Make the Competition Irrelevant. Brighton: Harvard Business School Press. 
Kim, W. Chan, and Renée Mauborgne. 2017a. The W. Chan Kim and Renée Mauborgne Blue Ocean Strategy Reader: The Iconic Articles by Bestselling Authors W. Chan Kim and Renée Mauborgne. Boston: Harvard Business Review Press.

Kim, W. Chan, and Renée Mauborgne. 2017b. Blue Ocean Shift: Beyond Competing_Proven Steps to Inspire Confidence and Seize New Growth. New York: Hachette Books.

Kim, W. Chan, Renée Mauborgne, Mi Ji, and Jee Eun Lee. 2013. Salesforce.com: Creating a Blue Ocean in the B2B Space. Boston: Harvard Business Publishing.

Kim, W. Chan, Renée Mauborgne, and Michael Olenick. 2016. The Marvel Way: Restoring a Blue Ocean. Boston: Harvard Business Publishing.

Klincewicz, Krzysztof. 2006. Praxiology: The International Annual of Practical Philosophy and Methodology. In Management Fashions: Turning Best-selling Ideas into Objects and Institutions. Piscataway: Transaction Publishers, vol. 13.

Kociatkiewicz, Jerzy, and Monika Kostera. 2016. Grand plots of management bestsellers: Learning from narrative and thematic coherence. Management Learning 47: 324-42. [CrossRef]

Kotter, John P. 1996. Leading Change. Boston: Harvard Business Press.

Kumaraswamy, Arun, Raghu Garud, and Shahzad Ansari. 2018. Perspectives on disruptive innovations. Journal of Management Studies 55: 1025-42. [CrossRef]

Leavy, Brian. 2005. Value pioneering-how to discover your own "blue ocean": Interview with W. Chan Kim and Renee Mauborgne. Strategy \& Leadership 33: 13-20.

Leavy, Brian. 2010. A system for innovating business models for breakaway growth. Strategy E Leadership 38: 5-15. [CrossRef]

Leavy, Brian. 2018. Value innovation and how to successfully incubate "blue ocean" initiatives. Strategy $\mathcal{E}$ Leadership 46: 10-20.

Lillrank, Paul. 1995. The transfer of management innovations from Japan. Organization Studies 16: 971-86. [CrossRef]

Lillrank, Paul. 2015. The anatomy of managerial panaceas: Ontology, epistemology and technology. In Handbook of Research on Management Ideas and Panaceas, Edward Elgar Publishing Limited, Cheltenham, UK. Edited by Anders Örtenblad. Cheltenham: Edward Elgar Publishing, pp. 25-34.

Loh, Kok Liang, Sha'ri Mohd Yusof, and Dominic H.C. Lau. 2018. Blue ocean leadership in lean sustainability. International Journal of Lean Six Sigma. [CrossRef]

Longbottom, David. 2000. Benchmarking in the UK: An empirical study of practitioners and academics. Benchmarking: An International Journal 7: 98-117. [CrossRef]

Low, Kim Cheng Patrick, and Sik-Liong Ang. 2013. Blue Ocean Strategy and CSR. In Encyclopedia of Corporate Social Responsibility. Edited by Samuel O. Idowu, Nicholas Capaldi, Liangrong Zu and Ananda Das Gupta. Berlin and Heidelberg: Springer, pp. 179-88.

Madsen, Dag, and Kåre Slåtten. 2013. The Role of the Management Fashion Arena in the Cross-National Diffusion of Management Concepts: The Case of the Balanced Scorecard in the Scandinavian Countries. Administrative Sciences 3: 110-42. [CrossRef]

Madsen, Dag Øivind. 2011. The Impact of the Balanced Scorecard in the Scandinavian Countries: A Comparative Study of Three National Management Fashion Markets. Ph.D. thesis, Norwegian School of Economics, Department of Strategy and Management, Bergen, Norway.

Madsen, Dag Øivind, and Kåre Slåtten. 2015a. Social media and management fashions. Cogent Business $\mathcal{E}$ Management 2: 1122256.

Madsen, Dag Øivind, and Kåre Slåtten. 2015b. The Balanced Scorecard: Fashion or Virus? Administrative Sciences 5: 90-124. [CrossRef]

Madsen, Dag Øivind. 2016a. Using Google Trends in management fashion research: A short note. European Journal of Management 16: 111-22. [CrossRef]

Madsen, Dag Øivind. 2016b. SWOT Analysis: A Management Fashion Perspective. International Journal of Business Research 16: 39-56. [CrossRef]

Madsen, Dag Øivind. 2017. Not dead yet: the rise, fall and persistence of the BCG Matrix. Problems and Perspectives in Management 15: 19-34. [CrossRef]

Madsen, Dag Øivind, Kåre Slåtten, and Daniel Johanson. 2017. The emergence and evolution of benchmarking: A management fashion perspective. Benchmarking: An International Journal 24: 775-805. [CrossRef] 
Massa, Lorenzo, and Christopher L. Tucci. 2013. Business model innovation. In The Oxford Handbook of Innovation Management. Edited by Mark Dodgson, David M. Gann and Nelson Philips. Oxford: Oxford University Press, pp. 420-41.

Mi, Ji. 2015. Blue Ocean Strategy. Hoboken: Wiley, p. 1.

Mol, Michael J., Nicolai Juul Foss, and Julian Birkinshaw. 2017. The System of Management Ideas: Origins, Microfoundations, and Dynamics. Available online: https:/ / ssrn.com/abstract=3046496 (accessed on 20 July 2018).

Morrison, Alan, and Robin Wensley. 1991. Boxing up or boxed in?: A short history of the Boston Consulting Group share/growth matrix. Journal of Marketing Management 7: 105-29. [CrossRef]

Narayana, Chem L., and Rom J. Markin. 1975. Consumer behavior and product performance: An alternative conceptualization. The Journal of Marketing 39: 1-6. [CrossRef]

Nijholt, Jurriaan, and Jos Benders. 2007. Coevolution in management fashions. Group E Organization Management 32: $628-52$.

Nørreklit, Hanne. 2003. The balanced scorecard: What is the score? A rhetorical analysis of the balanced scorecard. Accounting, Organizations and Society 28: 591-619. [CrossRef]

Örtenblad, Anders. 2007. The evolution of popular management ideas: An exploration and extension of the old wine in new bottles metaphor. International Journal of Management Concepts and Philosophy 2: 365-88. [CrossRef]

Parvinen, Petri, Jaakko Aspara, Joel Hietanen, and Sami Kajalo. 2011. Awareness, action and context-specificity of blue ocean practices in sales management. Management Decision 49: 1218-34. [CrossRef]

Perkmann, Markus, and Andrè Spicer. 2008. How are Management Fashions Institutionalized? The Role of Institutional Work. Human Relations 61: 811-44. [CrossRef]

Peters, Tom, and Robert Waterman. 1982. In Search of Excellence: Lessons from America's Best Run Companies. New York: Harper \& Row.

Pitta, Dennis. 2009. Issues in a down economy: Blue oceans and new product development. Journal of Product $\mathcal{E}$ Brand Management 18: 292-96.

Planellas, Marcel. 2017. The Evolution of Strategy (Over Six Decades and Thirty Models). ESADE Business School Research Paper No. 262. Available online: https:/ / papers.ssrn.com/sol3/papers.cfm?abstract_id=2926938 (accessed on 21 September 2018).

Prahalad, Coimbatore Krishnarao K., and Gary Hamel. 1990. The Core Competence of the Corporation. Harvard Business Review, 79-91.

Prahalad, Coimbatore K., and Gary Hamel. 1994. Strategy as a field of study: Why search for a new paradigm? Strategic Management Journal 15: 5-16. [CrossRef]

Ramli, Anis Safwan, Jasmine Binti Ahmad, and Norhafizah Mohamed Harith. 2016. Blue ocean strategy in Malaysian public sector: An analysis of the four action framework. Advanced Science Letters 22: 1702-6. [CrossRef]

Rasche, Andreas, and David Seidl. 2017. A Luhmannian perspective on strategy: Strategy as paradox and meta-communication. Critical Perspectives on Accounting. [CrossRef]

Rigby, Darrell. 2017. Management Tools 2017: An Executive's Guide. Boston: Bain \& Company, Inc.

Rigby, Darrell, and Barbara Bilodeau. 2018. Management Tools \& Trends. Boston: Bain \& Company, Inc.

Røvik, Kjell Arne. 1998. Moderne Organisasjoner. Oslo: Fagbokforlaget.

Røvik, Kjell Arne. 2002. The secrets of the winners: Management ideas that flow. In The Expansion of Management Knowledge: Carriers, Ideas and Sources. Edited by Kerstin Sahlin-Andersson and Lars Engwall. Stanford: Stanford University Press, pp. 113-44.

Sahlin-Andersson, Kerstin, and Lars Engwall. 2002. Carriers, Flows, and Sources of Management Knowledge. In The Expansion of Management Knowledge. Edited by Kerstin Sahlin-Andersson and Lars Engwall. Stanford: Stanford Business Books-Stanford University Press, pp. 3-32.

Savage, Carl, and Mats Brommels. 2008. Innovation in medical education: How Linköping created a Blue Ocean for medical education in Sweden. Medical Teacher 30: 501-7. [CrossRef] [PubMed]

Seidl, David. 2007. General strategy concepts and the ecology of strategy discourses: A systemic-discursive perspective. Organization Studies 28: 197-218. [CrossRef]

Širec, Karin, and Dijana Močnik. 2016. Indicators of Start-Ups' Adoption of Blue Ocean Strategy: Empirical Evidence for the Danube Region. International Review of Entrepreneurship 14: 265-88. 
Slocum, Philip C., and Frank Papa. 2014. Envisioning a global role for osteopathic medicine in the 21st century: Using Blue Ocean Strategy to promote osteopathic health care as the World's leader in healthcare education and do it more efficiently, effectively and at the lowest cost. International Journal of Osteopathic Medicine 17: 38-42. [CrossRef]

Spell, Chester. 1999. Where do management fashions come from, and how long do they stay? Journal of Management History 5: 334-48. [CrossRef]

Srinivas, Srikanth. 2015. A Blue Ocean Way of Getting into Shape: How to Peel Away the Pounds with Blue Ocean Strategy. Available online: https:/ / www.blueoceanstrategy.com/blog/blue-ocean-way-of-gettinginto-shape/ (accessed on 20 November 2018).

Stenfors, Sari. 2007. Strategy Tools and Strategy Toys: Management Tools in Strategy Work. Helsinki: Helsinki School of Economics.

Tabari, Mojtaba, Mehrdad Ziabari, Mona Radmard, and Mahdiyeh Radmard. 2014. The role of a blue ocean strategy on performance evaluation. Management Science Letters 4: 1611-18. [CrossRef]

Tassabehji, Rana, and Andrew Isherwood. 2014. Management use of strategic tools for innovating during turbulent times. Strategic Change 23: 63-80. [CrossRef]

The Economist. 2009. Gurus: Robert Kaplan and David Norton. The Economist, June 26.

Ulrich, Dave. 1998. A new mandate for human resources. Harvard Business Review 76: 124-35. [PubMed]

Welch, Shari J., and Bob Edmondson. 2012. Commentary: Applying blue ocean strategy to the foundation of accountable care. American Journal of Medical Quality 27: 256-57. [CrossRef] [PubMed]

Wittrock, Christian. 2015. Reembedding Lean: The Japanese Cultural and Religious Context of a World Changing Management Concept. International Journal of Sociology 45: 95-111. [CrossRef]

(C) 2019 by the authors. Licensee MDPI, Basel, Switzerland. This article is an open access article distributed under the terms and conditions of the Creative Commons Attribution (CC BY) license (http:/ / creativecommons.org/licenses/by/4.0/). 